\title{
"0 rádio está morto... Viva o som!" ou como o rádio pode se transformar em uma nova mídia ${ }^{1}$
}

/////////////////I Armand Balsebre

1. Tradução do texto da conferência ministrada pelo autor no Radio Evolution Congress 2011, evento organizado pela Seção de Rádio da Ecrea (European Communication Research and Education Association) e realizado na Universidade do Minho (Braga, Portugal), entre os dias 14 e 16 de setembro de 2011.

2. Catedrático de comunicação audiovisual e publicidade e diretor do Publiradio, grupo de investigação da Universidade Autônoma de Barcelona. E-mail: armand.balsebre@uab.es 
Resumo

O texto que se segue é a versão para o português da conferência ministrada pelo autor na Universidade do Minho (Braga, Portugal) durante o Radio Evolution Congress 2011, evento organizado pela Seção de Rádio da crea (European Communication Research and Education Association). Sua intenção é discutir os desafios hoje colocados diante do rádio para que ele se converta numa nova mídia sonora, no contexto da nova "sonosfera", para os novos radiouvintes. Falando especialmente sobre a situação do rádio na Espanha, a posição do autor é a de que o rádio, para obter sucesso nesse novo cenário, deverá focar em sua condição de mídia exclusivamente sonora e numa nova audiência que considera que a mediação dos meios tradicionais já não é necessária.

\section{Palavras-chave}

Rádio, rádio na Espanha, nova “sonosfera”.

Abstract

The present article is the Portuguese translated version for the presentation given by the author at the University of Minho (Braga, Portugal) during the Radio Evolution Congress 2011, an event organized by the Ecrea (European Communication Research and Education Association). It aims to debate on the challenges currently faced by radio media as to become a new sound media in the context of a new soundscape or sound-sphere, for the new listeners. As the author focuses especially on the situation of radio in Spain, he stands that for radio to be successful in such scenario it has to focus on the aspect of being an exclusively sound media and also focus on a new audience which understands that the mediation performed by traditional means of communication is no longer needed.

\section{Keywords}

Radio, radio in Spain, new sound-sphere. 
3. N.T.: preferi manter a maioria das marcas de oralidade presentes no texto original.
Bom dia ${ }^{3}$. Agradeço à Seção de Rádio da Ecrea pela oportunidade de estar aqui hoje, neste congresso internacional. E minhas felicitações à Universidade do Minho pela estupenda organização.

“O rádio está morto... Viva o som!". Esse é o título que escolhi para minha intervenção neste congresso sobre a evolução do rádio.

“Viva o som!"... porque o som é um elemento vital para criar e contar uma boa história. Desde que, é claro, ela seja transmitida por um bom comunicador, conhecedor de todos os segredos da linguagem sonora e, também, de todos os segredos da percepção sonora. Quer dizer: conhecedor de como o som pode causar uma emoção indelével no coração dos ouvintes. Porque a estrutura narrativa de uma história e a qualidade do som empregado para transmiti-la (o som da voz, o som da música) são elementos imprescindíveis para lograr um impacto emocional na audiência.

A compreensão desse título - "O rádio está morto... Viva o som!” - necessita de perguntas complementares: o rádio pode chegar a se converter em uma nova mídia sonora, no contexto da nova "sonosfera", para os novos ouvintes? Pode o rádio constituir-se na principal referência das novas mídias sonoras, independentemente dos aparatos tecnológicos de reprodução que possam ser utilizados?

A resposta a essas perguntas exige que se tenha em conta o posicionamento que, espero eu, terá o rádio na nova "sonosfera”, na qual os meios tradicionais irão conviver com os novos meios. Dessa perspectiva... 
- Se o rádio não continuar subestimando a importância de ter uma boa história, de ter vozes de grande qualidade, boas histórias sonoras, bem narradas, ou não continuar subestimando a importância de ter um bom departamento especializado em criatividade sonora...

- Se o rádio souber como preencher esse implacável minuto com 60 segundos de palavras precisas, exatas e souber lutar com dignidade contra o palavrório gratuito e sem sentido que nos acostumamos a escutar diariamente por suas ondas...

- Se o rádio souber como chegar a ser uma das melhores plataformas para a transmissão da arte sonora, um dos melhores canais para a comunicação pública, para o relato da atualidade e uma das melhores companhias que possamos ter nos momentos de solidão...

- E, finalmente, se souber como investir mais dinheiro em conteúdos, em lugar de investir mais dinheiro em tecnologia...

Então: o rádio poderá chegar a ser um novo meio sonoro da nova "sonosfera", para os novos radiouvintes, em qualquer contexto tecnológico de reprodução sonora.

O desafio que terá o rádio na nova “sonosfera”, em busca de uma nova identidade, tentando renascer de uma morte tantas vezes anunciada, depende de como o rádio irá aprender a tirar vantagem de sua aparente desvantagem: o rádio é apenas uma mídia sonora. Se quiser chegar a ser uma nova mídia, o rádio nunca deverá esquecer essa questão: ele é apenas uma mídia sonora. Logicamente, entendo esse "apenas" como algo positivo, não como uma limitação. Bemvindo seja esse apenas!

Essa questão introduz no debate um interessante paradoxo, objetivo principal desta conferência: se o rádio quiser chegar a converter-se numa nova mídia, terá que respeitar sua tradicional e particular estrutura comunicativa sonora.

Por exemplo: o rádio tem que reduzir a energia que dedica a esse enorme esforço para mostrar, no lugar de contar. O rádio tem que frear uma tendência estratégica e de posicionamento, muito em voga, que consiste em situar o som que o representa num contexto 
gráfico e visual, como se uma emissora de rádio tivesse que ter a mesma identidade de um canal de televisão em uma página da web. O rádio tem que se dedicar mais a contar, contar histórias com sons, em lugar de mostrar imagens digitais em uma página da web. E esse "contar histórias com sons" pode ser perfeitamente compatível com o fato de que, graças à imaginação, esses sons podem converter-se em imagens mentais tão fascinantes como as imagens que vemos na televisão.

Recordemos!: o rádio tem estado a ponto de morrer desde a década de 1970. E esse tem sido um tópico inevitável. Todos falamos com frequência da morte do rádio. Mas o rádio, em busca de uma nova identidade, tem sido capaz de sobreviver a essa morte tantas vezes anunciada.

Recordemos o grande desafio que afrontou a identidade do rádio nos anos 1970 em relação à evolução da televisão. O rádio soube encontrar uma nova identidade como meio especializado em notícias, revistas de atualidade, programas de conversa com os ouvintes e veiculação musical. E, nesse trânsito, o rádio perdeu sua programação de entretenimento. Os concursos e os programas dramáticos desapareceram da grade de programação das emissoras e migraram para a televisão. Ainda hoje a televisão é o principal meio para os concursos e para a ficção.

Quando, nos anos 1990, a televisão deu um grande salto com os reality shows, um bom formato para lutar contra as crises econômicas, o rádio apenas reagiu. E perdeu, frente à internet, seu papel de "caixa de música". Ao mesmo tempo, a crise econômica obrigou as companhias fonográficas a uma grande autorregulação. A idade de ouro dessas empresas havia terminado. Para entender melhor o poder que teve o rádio nesse contexto, temos de recordar que o rádio chegou a ser o "braço armado" da indústria fonográfica.

A resposta da rádio à crise dos anos 1990 foi o fortalecimento de seu star system, com a contratação de locutores muito populares e uma programação com mais horas dedicadas à atualidade: notícias, entrevistas, magazines, talk shows, debates políticos e late night shows, nos quais os ouvintes eram convidados a contar por telefone seus segredos mais íntimos. 
A imagem estereotipada na Espanha de um locutor de rádio não está representada pela imagem de um showman ou de uma showwoman, ou pela imagem de um disc jockey, mas sim pela de um jornalista que narra a atualidade, que entrevista personagens da vida cultural e política três, quatro ou seis horas por dia.

Mesmo quando a televisão se converte num meio falado, com programas em que uma série de personagens se reúne ao redor de uma mesa para falar e só falar, o rádio não tem sabido tirar partido dessa influência. Porque uma parte significativa da programação televisiva, hoje, não é outra coisa senão rádio numa tela de televisão. O rádio perdeu nos anos 90 a oportunidade de erigir-se na principal referência enquanto mídia sonora: um setor importante do star system televisivo havia nascido no rádio, e esse star system surgia na televisão fazendo programas de rádio. E mais: foram introduzidas câmeras de televisão nos estúdios de rádio, para mostrar aos telespectadores como se fazia um programa. Os responsáveis pelas emissoras de rádio acreditaram, talvez, que, se a audiência fosse capaz de olhar o rádio, esse meio sonoro ganharia em audiência. Mas esqueceram que a virtude mais importante do rádio, até o presente, é a sua invisibilidade. E é na invisibilidade que está realmente a diferença.

Foi somente a partir das sombras, falando a audiências invisíveis, contando uma história, explorando novos mundos em nossa imaginação que o rádio logrou chegar a ser o meio tão particular e pessoal que hoje é. Porque, se não somos capazes de ver, somos capazes de escutar os sons muito melhor. Essa verdade, do âmbito da psicologia e da percepção, deveria constituir-se no lema principal dos responsáveis pela programação das emissoras de rádio. Somente a partir das sombras o rádio chegará a ser um novo meio, na busca de uma nova identidade, na nova "sonosfera", evitando assim ser absorvido por outros meios. Somente a partir das sombras o rádio continuará desfrutando de seu diferencial e nunca morrerá.

E agora, na era das novas mídias, uma vez mais se fala da morte do rádio. Mas o rádio não está morto. E não só porque a Ecrea e a Universidade do Minho conseguiram reunir com êxito em Braga quase 200 pesquisadores de rádio de todo o mundo - o que já é 
por si só uma razão importante — , mas porque o rádio é, ainda, um meio que goza de grande popularidade.

Enquanto nós estamos aqui em Braga falando do rádio, milhões e milhões de pessoas em todo o mundo estão agora mesmo a escutálo. Sintonizam uma emissora porque a audição de rádio é para eles um hábito cotidiano, profundamente arraigado em sua rotina diária. Escutam o rádio porque é um costume tão habitual como respirar, como comer, como conduzir um veículo...

O problema talvez tenha começado quando as empresas de mídia, proprietárias de periódicos, canais de televisão e emissoras de rádio, deixaram de acreditar no poder do veículo. Na grande teia de interesses econômicos que vincula a publicidade com a audiência, o rádio se converteu, para essas empresas, em uma simples mídia complementar.

A primeira coisa que as grandes empresas que operam emissoras de rádio devem reconhecer é o poder do som. Apesar do poder de sedução e persuasão que tem a imagem na tela da televisão ou em qualquer outra tela digital, o som também tem um grande poder:

- podemos imaginar o espírito de nossos jovens sem a música? O som da música é essencial para as vidas de muitas pessoas.

- Podemos imaginar o poder persuasivo de um spot televisivo sem o som da música ou das vozes dos atores?

- Podemos imaginar o mundo sem uma "caixa de som"?

Pois o rádio pode ser a “caixa de som” do futuro. Talvez não um rádio como o temos entendido até o presente, mas sim um rádio com uma programação melhor, orientada a uma audiência que seja capaz de valorar o som como uma questão essencial.

Meu grupo de investigação na Universidade Autônoma de Barcelona, Publiradio, tem estudado o que acontece com a audiência que está fora do sistema de medição de audiências convencional: a audiência composta por crianças menores de 14 anos. Esse segmento constitui um universo desconhecido, uma audiência invisível, excluída, mas que escuta o rádio habitualmente: no automóvel familiar, na escola, no telefone celular, ou enquanto 
4. A produção pode ser ouvida em: $<$ http://752118746.radioactividades. com.uy/s. realiza os deveres de casa. É uma audiência que incorporou à sua rotina diária o hábito de ouvir rádio como algo normal. É muito possível que essa jovem audiência às vezes ignore que o som que escuta em seus fones vem de uma emissora de rádio. Mas se trata de uma audiência fascinada pelo poder do som; o som da música na maioria das vezes, é claro, mas também o som de algumas vozes extraordinárias, como a do ator de rádio, teatro e dublagem Constantino Romero, que assumiu o papel do protagonista na versão espanhola da emissão de Orson Welles A guerra dos mundos, que ele produziu e adaptou para a cadeia SER em 1988. Muitos jovens ouvintes ficaram fascinados pela voz de Constantino Romero interpretando o professor Pierson no monólogo final de A guerra dos mundos ${ }^{4}$. A voz de Constantino e a habilidade narrativa de Welles são uma garantia de sucesso.

Então, onde está o problema?

Problema n. 1: A “sonosfera” que envolve a jovem audiência não é entendida como pertencente ao universo do rádio. O som que muitos jovens ouvintes escutam em seus fones é considerado unicamente como "música", ou "audiolivro", ou som precedente da televisão, especialmente quando nossos olhos não estão voltados para a tela da TV. Por exemplo, muitos jovens provavelmente escutaram algum fragmento de A guerra dos mundos, interpretada por Constantino Romero, em algum site da internet, ignorando que ele é procedente de uma emissão radiofônica. Tudo de que o rádio necessita é saber como melhorar sua imagem corporativa, que o identifique como a principal referência sonora entre os diferentes meios e plataformas de comunicação.

Problema n. 2: O rádio deixou o papel de principal referência sonora: a) com a destruição dos departamentos de ficção, que constituíam uma de suas fontes de entretenimento mais eficazes e baratas; b) com a transferência de seu papel de "caixa de música" para a internet. A nossa principal “caixa de música” é agora o computador ou qualquer periférico conectado à internet.

O que está a ponto de morrer, talvez, é o aparato receptor convencional do rádio, ou a maneira tradicional pela qual temos 
escutado rádio até agora. A audição do rádio está submetida hoje a um âmbito tecnológico mais sofisticado. Até o presente, imaginávamos o rádio como uma voz dentro de uma caixa. Essa ideia, essa imagem, desapareceu da mente de nossas jovens audiências. Para elas, o som já não procede de uma caixa, ainda que tal caixa, por exemplo, possa ser um dispositivo tão moderno como um e-book. O som procede de dentro, de seu interior, e não de fora, porque nossos ouvidos eletrônicos, os fones auriculares, passaram a ser os ouvidos naturais de muitos jovens. Tudo de que o rádio necessita é saber como acender seu circuito de atenção e como se conectar com os novos ouvintes, com boas histórias sonoras bem narradas.

Problema n. 3: Nesse novo âmbito tecnológico, o rádio trabalha com um novo contexto comunicativo: as novas audiências estão pondo em crise o circuito tradicional da mediação. A legitimidade dos meios se baseava nesta regra: um meio é um canal de mediação entre a realidade e as audiências. Mas agora as novas audiências, a nova geração digital, fascinada pela questão mágica da interatividade na internet, exige uma comunicação sem a mediação dos meios. Essa nova audiência, se estiver em um teatro, por exemplo, apreciará estar ao mesmo tempo na área de fumantes e no cenário, ficar observando e sendo observada, ser ouvinte e locutora. Essa nova audiência considera que a mediação dos meios tradicionais já não é necessária. Temos de entender o futuro do rádio a partir desse novo ouvinte, que deseja ser o centro da comunicação.

Tudo de que o rádio necessita é saber como planejar novos formatos adaptados à luta contra a crise da mediação. Mas tendo em conta também, simultaneamente, que o rádio é muito mais que um canal a serviço da comunicação entre os próprios ouvintes em talk shows, ou que o rádio é muito mais que um canal para a radiodifusão de notícias de serviço público. A linguagem radiofônica sempre necessitará de bons narradores, treinados na arte de contar histórias com sons para uma audiência invisível. O rádio necessita de um âmbito artístico se quer ser algo mais que uma "caixa de música” ou uma "caixa de palavras". 
Mas voltemos ao princípio. É importante regressar ao princípio algumas vezes porque, no princípio, era o som. O som em grandes cavernas, quando o homem golpeava pedras com ossos e escutava o som de sua própria voz, amplificada pela reverberação das paredes da caverna. O homem conheceu o poder do som desde o princípio, e até antes, escutando a voz de sua mãe ainda antes de nascer. Assim, o som tem sido nosso companheiro desde o princípio do princípio.

O que o homem tem buscado, desde o início, é saber como construir instrumentos para produzir sons, ou instrumentos para enviar sons a longas distâncias. Foi assim que nasceu o rádio.

O rádio tem sentido porque é uma mídia que nos ajuda a ouvir nossas próprias vozes, as vozes do nosso entorno, os sons de nossas emoções. A necessidade do homem de escutar é a melhor razão para justificar a necessidade do rádio. É por isso que entendo que o rádio, como a melhor paisagem sonora de nossa sociedade, jamais desaparecerá.

O implacável passo do tempo, nosso antipático amigo no rádio, recorda-me que esta conferência está terminando. Muito obrigado.

* O texto foi fornecido pelo autor em espanhol e traduzido por Eduardo Vicente. 